\title{
COMPARATIVE ANALYSIS OF THE INFLUENCE ON CONSUMERS VIA MOBILE PHONES AND COMPUTERS
}

\author{
UDC: 004:339.138 \\ Original Scientific Paper
Milica JEVREMOVIĆ ${ }^{1}$, Velimir ŠTAVLJANIN ${ }^{2}$, Živorad VASIĆ ${ }^{1}$, Milomir STANKOVIĆ ${ }^{3}$ \\ ${ }^{1}$ School of Electrical Engineering and Computer Science Applied Studies, 11000 Belgrade, Vojvode Stepe 283, \\ Republic of Serbia \\ E-mail: milicag@ viser.edu.rs \\ ${ }^{2}$ University of Belgrade, Faculty of Organizational Sciences, Marketing Management and Public Relations \\ Department, 11000 Belgrade, Jove Ilića 154, Republic of Serbia \\ ${ }^{3}$ School of Business and Technical Science, Doboj, Ozrenskih Serbian Brigade, No. 5A 74000, Bosnia and
}

Herzegovina

Paper received: 29.03.2016.; Paper accepted: 03.05.2016.

\begin{abstract}
Business operations are nowadays characterized by a rapid development of technology and marketers are therefore searching for most efficient methods for drawing the attention of consumers to their business and occupying a position in their consciousness. The possession and use of mobile phones have become an integral part of lives of all consumers. This work investigates whether there are any differences in the degree of influencing consumers who watch advertising content via their mobile phones, in comparison to the influence on those watching the same content on computers, and how big they are, as well as whether the opinion of respondents concerning interactivity (perceived interactivity) of the observed content differs from the actual, existing interactivity.
\end{abstract}

Keywords: Perceived interactivity, Consumers, Mobile marketing.

\section{INTRODUCTION}

The former research by authors in the field of Internet Marketing has mainly pertained to the optimization, promotion, possibilities of increasing the Internet traffic, website traffic analysis. Having understood the significance of the concept of interactivity, which is permanently present in Internet Marketing, the authors shift their focus to the research of the concept of interactivity for the purpose of better Internet promotion (Vasic et al., 2011).

Surveys dealing with business trends of companies testify to the fact that advertisers are increasingly turning to mobile marketing, believing that such a method of investing in marketing will be most cost-effective. In 2011, an increase in mobile advertising compared with advertising via e-mail and social networks was observed, and it was then foreseen that the growth rate of mobile advertising would increase to USD 8.2 billion until 2016 (VanBoskirk, 2011). A survey conducted in 2011 referred to the USA, which was considered the leading country in the world of marketing. It was determined that the reasons for such development were the following: the understanding of marketers that mobile phones are increasingly used, that mobile advertisements are always present around users for better targeting of advertising and dynamic contents, increased trade via mobile phones leads to increased investments in mobile advertising.

The author of a large number of books dealing with digital marketing, Dave Chaffey, speaks in his report about the influence of new digital media trends on marketing (Chaffey, 2016). He states that by 2016 the use of mobile phones for marketing purposes will constantly increase and become the main method for acquiring information in 2016. 


\section{MOBILE MARKETING}

Mobile marketing is defined as the use of wireless media for turning the information about time and precise locations of consumers into personal information which promotes products, services and ideas (Scharl et al., 2005).

Mobile marketing is the most personal form of web marketing (Krum, 2010). The use of mobile phones makes it possible to obtain all the information needed for a company to approach its consumers, to understand the consumers' way of thinking, their needs and desires, how and when they wish to receive the advertising message, etc. In this manner the consumers become available 24 hours a day, 7 days a week. This helps advertisers to create the overall marketing campaign. The consumers' need for being constantly informed has always existed; the occurrence and frequent use of mobile phones have only facilitated the satisfaction of this need (Michael \& Salter, 2006).

Some of the key features of mobile marketing are the following (Smutkupt et all., 2010): omnipresence, personalization, two-way communication, localization, and these features offer unlimited business opportunities.

The activities influencing an increase in awareness of an advertised brand which are included in mobile marketing are the following: mobile advertising, short text messages, location-based mobile marketing, mobile applications, mobile search marketing, online marketing on websites, in searches and e-mail (Krum, 2010).

Some of the advantages of mobile marketing are the following: higher response rate, lower investment cost, lower effort degree for the commencement of communication (Michael \& Salter 2006).

Frequent use of mobile phones, in addition to the fact that it has changed the perception of consumer availability, offers a series of advantages: it is costeffective, stable, targeted, personal, sharable, portable, flexible, interactive, immediate, measurable, effective, efficient, repeatable and entertaining. (Krum, 2010). Mobile marketing includes: advertisement, sales, promotion and direct marketing (Matti \& Heikki 2008).

\section{MARKETING PERFORMANCE MEASUREMENT}

All analytics packages supporting mobile devices ensure special monitoring of consumers who have accessed the content both via a computer or via mobile devices, which includes: total number of visits, single visits, total page view, page view per visit, visit duration, single page view ratio, new visitors, repeated visits, organic searches, paid searches, source of visits, visits with conversation, visits with transactions, access pages, key words, browsers used to access the Internet, operating system used, etc. (Pasqua \& Elkin 2013).

One of the software solutions offered free of charge for monitoring the behavior of consumers on the Internet is Google Analytics, which shows how users find and use the website, dividing the monitoring parameters into users accessing the content via a computer and via other devices, which enables advertisers to make higher quality decisions on the website design and content as well as on the overall upcoming marketing campaign. Google Analytics provides detailed statistics of the website traffic, including the number of visits, pages viewed, average visit duration, use of key words for searches, both in real time and for a desired period. Users may be monitored by age, gender, geographic location, inclinations, interests, etc.

The use of mobile phones also offers a number of specialized analytics tools. If you invest in mobile applications and if you want to monitor the use of such applications, you should use Localytics, Mobilytics and Flurry. These analytics packages should provide information about the frequency of use, average duration and total time spent on a website (Pasqua \&Elkin 2013).

The effect on users is associated with the concept of interactivity, i.e. with the users' understanding of possible two-way communication in real time by the company being advertised. Interactivity and its perception by users influence the user satisfaction and formation of an attitude towards the company and its presentation on the Internet. By studying the concept of interactivity we can observe a difference between the perceived and actual interactivity (Figure 1), where the perceived interactivity determines further user behavior towards the company but does not influence a direct increase in the final user action, regardless of whether it is about the purchase of a 
product/service, signing up for an advertised content, etc.

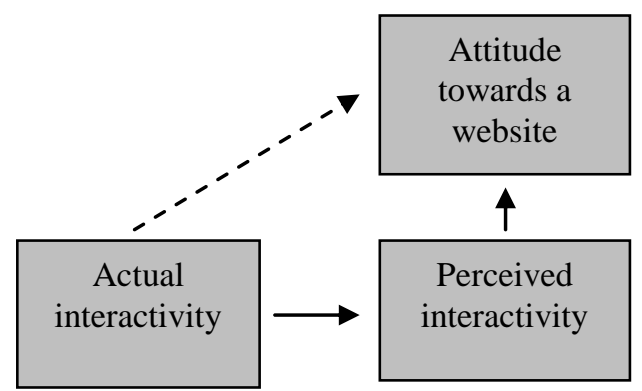

Figure 1: Perceived and actual interactivity, and attitude towards a website (Wu, 2005)

A large number of authors have dealt with the measurement of perceived interactivity (Newhagen et al., 1995; Hoffman, Novak, 1996; Wu, 1999; Shankar et al., 2003; Yuping, 2003; Chung \& Zhao, 2004; Wu, 2005; Wu, 2006; Song \& Zinkhan 2008); we have decided to present the model of Song and Zinkan (Song \& Zinkhan 2008) in this survey, as a model which in the simplest and most comprehensive manner includes all parameters needed for measuring the perceived interactivity. This model differentiates between properties of the medium, which is an essential determinant of the perceived interactivity, and the message quality as a precondition for website interactivity. The authors use the following parameters for interactivity measurement: Communication, Control, Possibility of Response, Attitude towards a Website, User Satisfaction, Overall Website Quality, Loyalty Intention, Repeated Orders and WOM.

When measuring the influence of marketers on consumers it is also necessary to define the key success indicators. An evident success indicator for presentation on the Internet is a click, but there are also other indicators that should be taken into consideration during the optimization for mobile advertising. The first action expected within an advertisement is (Pasqua \&Elkin 2013): a click on invitation, click on map or store location, click on offer, click on another access page or microsite, click on application download, click on screen containing an application, time spent on advertising experience, actions completed within advertising experience.

\section{SURVEY}

A survey has been conducted at the College of Electrical Engineering for the purpose of determining different effects on respondents accessing the content via mobile devices and those accessing the content via computers. By analyzing the literature, it has been determined that in most cases a website has been used as a stimulus for investigating the interactivity between consumers and advertisers (Wu 1999; Downes \& Mcmillan 2000; Liu \& Shrum 2002; McMillan \& Hwang 2002; McMillan 2002; Liu, 2003; Albert et all., 2004; Johnson et all., 2006; Wu, 2006; Song \& Zinkhan ,2008; Jiang et all., 2010). For that reason, the content has been presented to responders via a website.

The survey website has been created taking into account that its layout should be adjusted to mobile devices. All elements of the website displayed on a computer are also present in the website displayed on mobile devices, but in a different manner due to the difference in the screen width (Figure 2). Navigation is displayed as a dropdown menu listing all pages and advertisements within pages. Quick links are displayed one below another. Articles are displayed one below another, as in the website layout on a computer. Auxiliary content elements and add-ons are displayed one below another as well. The only website element that is not displayed on mobile devices is the banner on the homepage.

\section{Survey stages}

In the first stage, which involved 350 respondents, the objective was to single out the respondents having the same or similar interests. All the respondents were first-year students at the College of Electrical Engineering who selected the subject Digital Multimedia 1. On the basis of the first stage results, we singled out 120 respondents searching for jobs/practice or training courses on websites.

In the second stage, the respondents singled out were tested in the computer laboratory with 20 computers having the same configuration and connected to the Internet via a $1,000 \mathrm{Mb} / \mathrm{s}$ Internet link with the academic network, in 6 groups of 20 respondents. The respondents were also provided with the local wireless computer network in compliance with the IEEE $802.11 \mathrm{G}$ standard, which enabled the respondents watching websites via mobile devices to participate in the survey without hindrance. Respondents were given slips of paper with the website address they should visit and a note indicating which device they should use, where it was taken into account that the total 
number of respondents in both categories should be equal. All respondents, after receiving the same instructions, were given 30 minutes to view the obtained website. After expiry of this period, the respondents were given the survey questionnaire and unlimited time for its completion. The objective of the survey questionnaire was to show whether and in what segments the respondents were satisfied with the interactivity of the obtained website. The survey questionnaire was prepared based on survey questionnaires used in the works of authors studying perceived interactivity (Song \& Zinkhan 2008; Yuping 2003; McMillan et all., 2002a; Wu 1999; Qin et all., 2010;Wu, 2006; Yuping \& Shrum, 2002).

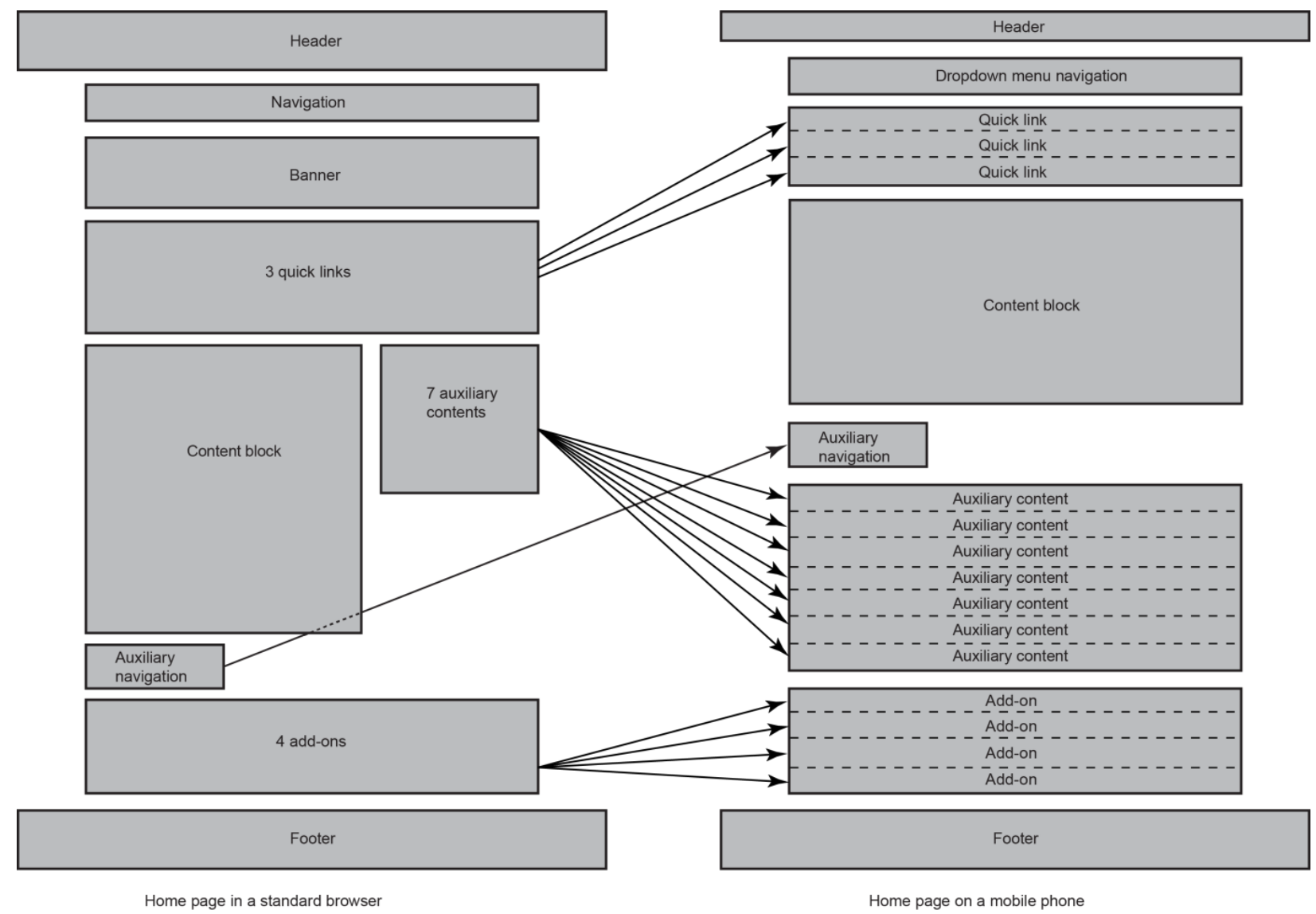

Figure 2: Differences between home page layouts on a computer (left) and on a mobile phone (right)

In the third stage, the data were processed and the survey results were presented. Upon the entry of data from the survey questionnaire it was noticed that some of the survey questionnaires were filled out inaccurately. They were eliminated from further analysis. After the entry of all the respondents' results, it was concluded that the number of respondents viewing the website via mobile devices was 49 , while the number of respondents who viewed the website on a computer was 51 , which impaired the number of respondents by the respective categories. For that reason, a uniformity analysis was performed by the number of respondents, and the obtained results $\left(\chi^{2}=0,005, p=0,943\right)$ showed that the processing of results could be continued.

\section{Survey results}

Statistical data processing and analysis were performed in the program SPSS ver. 20 (Statistical Package for the Social Sciences). Statistical significance was defined at the null hypothesis probability level from $p \leq 0.05$ to $p<0.01$. The difference between respondents using computers and those using mobile devices was determined by the use of a T-test for large independent samples.

The differences in understanding the achieved perceived interactivity can be seen in Table 1. A difference between the respondents using computers and those using mobile devices exists in the highlighted fields in column $\mathrm{p}$, where $\mathrm{p}<0.05$. Statistically significant differences can be seen in 
M. Jevremović et al. Comparative analysis of the influence on consumers via

mobile phones and computers

categories Possibility of Response, Consumer Satisfaction, Loyalty Intention, where in all the three observed categories the respondents using the website via mobile devices had a stronger impression:

- obtaining a quick, adequate and accurate response,

- satisfaction after using the website,
- they will remain loyal to the website use and give positive recommendations for the viewed website

The respondents' answers to the questions from the survey questionnaire are provided in Table 2. Statistically significant differences are highlighted in questions where $p<0.05$.

Table 1: Overview of differences in categories of the SONG model

\begin{tabular}{|c|c|c|c|c|c|}
\hline & Device used & $\mathbf{M}$ & SD & $\mathbf{t}$ & $\mathbf{p}$ \\
\hline \multirow{2}{*}{ SONG model } & Computer & 5.1485 & .58707 & \multirow{2}{*}{-1.928} & \multirow{2}{*}{.057} \\
\hline & Mobile device & 5.3643 & .52866 & & \\
\hline \multirow{2}{*}{ Communication } & Computer & 4.5098 & 1.07363 & \multirow{2}{*}{.088} & \multirow{2}{*}{.930} \\
\hline & Mobile device & 4.4932 & .79710 & & \\
\hline \multirow{2}{*}{ Control } & Computer & 5.8848 & .68504 & \multirow{2}{*}{.473} & \multirow{2}{*}{.637} \\
\hline & Mobile device & 5.8163 & .76210 & & \\
\hline \multirow{2}{*}{ Possibility of Response } & Computer & 5.1242 & .74524 & \multirow{2}{*}{-2.033} & \multirow{2}{*}{.045} \\
\hline & Mobile device & 5.4558 & .88243 & & \\
\hline \multirow{2}{*}{$\begin{array}{l}\text { Attitude towards the } \\
\text { website }\end{array}$} & Computer & 5.7516 & 1.09106 & \multirow{2}{*}{-1.536} & \multirow{2}{*}{.128} \\
\hline & Mobile device & 6.0544 & .86160 & & \\
\hline \multirow{2}{*}{ Satisfaction } & Computer & 4.6797 & .93799 & \multirow{2}{*}{-2.036} & \multirow{2}{*}{.044} \\
\hline & Mobile device & 5.0544 & .90099 & & \\
\hline \multirow{2}{*}{ Overall website quality } & Computer & 5.5294 & 1.00206 & \multirow{2}{*}{-.988} & \multirow{2}{*}{.325} \\
\hline & Mobile device & 5.7143 & .85999 & & \\
\hline \multirow{2}{*}{ Loyalty intention } & Computer & 4.7843 & 1.49444 & \multirow{2}{*}{-2.503} & \multirow{2}{*}{.014} \\
\hline & Mobile device & 5.4776 & 1.26017 & & \\
\hline
\end{tabular}

$\mathrm{M}$ - Arithmetic mean; SD - Standard deviation; $\mathrm{t}$ - the t-test, $\mathrm{p}$ - Statistical significance

Table 2: Overview of differences in questions of the SONG model

\begin{tabular}{|c|c|c|c|c|c|}
\hline & Device used & M & SD & $\mathbf{t}$ & $\mathbf{p}$ \\
\hline \multicolumn{6}{|l|}{ COMMUNICATION } \\
\hline \multirow{2}{*}{ The website facilitates two-way communication } & Computer & 4.7451 & 1.33930 & \multirow{2}{*}{-1.311} & \multirow{2}{*}{.193} \\
\hline & Mobile device & 5.0816 & 1.22196 & & \\
\hline \multirow{2}{*}{$\begin{array}{l}\text { The website offers a possibility for live } \\
\text { communication with a company representative }\end{array}$} & Computer & 4.2941 & 1.93178 & \multirow{2}{*}{.181} & \multirow{2}{*}{.857} \\
\hline & Mobile device & 4.2245 & 1.91774 & & \\
\hline \multirow{2}{*}{$\begin{array}{l}\text { The website enables simultaneous } \\
\text { communication of a number of users }\end{array}$} & Computer & 4.3333 & 1.87261 & \multirow{2}{*}{.879} & \multirow{2}{*}{.381} \\
\hline & Mobile device & 4.0204 & 1.67692 & & \\
\hline \multirow{2}{*}{ The website enables conversation } & Computer & 4.3333 & 1.95619 & \multirow{2}{*}{-1.163} & \multirow{2}{*}{.248} \\
\hline & Mobile device & 4.7755 & 1.84012 & & \\
\hline \multirow{2}{*}{ The website is effective in collecting feedback } & Computer & 5.1961 & 1.09580 & \multirow{2}{*}{-1.429} & \multirow{2}{*}{.156} \\
\hline & Mobile device & 5.5102 & 1.10156 & & \\
\hline \multirow{2}{*}{$\begin{array}{l}\text { The website does not offer a possibility of live } \\
\text { communication with a company representative }\end{array}$} & Computer & 4.1569 & 1.86947 & \multirow{2}{*}{2.214} & \multirow{2}{*}{.029} \\
\hline & Mobile device & 3.3469 & 1.78595 & & \\
\hline \multicolumn{6}{|l|}{ CONTROL } \\
\hline \multirow{2}{*}{$\begin{array}{l}\text { While I was on the website, I was aware of my } \\
\text { exact location all the time }\end{array}$} & Computer & 6.1765 & 1.26025 & \multirow{2}{*}{.052} & \multirow{2}{*}{.958} \\
\hline & Mobile device & 6.1633 & 1.26404 & & \\
\hline \multirow{2}{*}{$\begin{array}{l}\text { While I was on the website I always knew } \\
\text { where I was going }\end{array}$} & Computer & 6.0980 & 1.08176 & \multirow{2}{*}{-1.448} & \multirow{2}{*}{.151} \\
\hline & Mobile device & 6.4082 & 1.05906 & & \\
\hline \multirow{2}{*}{$\begin{array}{l}\text { While I was on the website, I could freely } \\
\text { select what exactly I wanted to watch }\end{array}$} & Computer & 6.4314 & 1.00509 & \multirow{2}{*}{-.163} & \multirow{2}{*}{.871} \\
\hline & Mobile device & 6.4694 & 1.30866 & & \\
\hline \multirow{2}{*}{$\begin{array}{l}\text { While I was navigating the website, my } \\
\text { actions determined the experience I obtained }\end{array}$} & Computer & 5.4706 & 1.33196 & \multirow{2}{*}{-.230} & \multirow{2}{*}{.819} \\
\hline & Mobile device & 5.5306 & 1.27642 & & \\
\hline \multirow{2}{*}{$\begin{array}{l}\text { While I was on the website, I was always able } \\
\text { to go where I wanted to go }\end{array}$} & Computer & 6.0588 & 1.13863 & \multirow{2}{*}{.318} & 751 \\
\hline & Mobile device & 5.9796 & 1.34613 & & .151 \\
\hline
\end{tabular}


M. Jevremović et al. Comparative analysis of the influence on consumers via

mobile phones and computers

Table 2 (continued): Overview of differences in questions of the SONG model

\begin{tabular}{|c|c|c|c|c|c|}
\hline \multirow{2}{*}{$\begin{array}{l}\text { I was satisfied for being able to select the link } \\
\text { I wanted and the time I wanted to click on it }\end{array}$} & Computer & 6.1373 & 1.51023 & \multirow{2}{*}{-1.140} & \multirow{2}{*}{.257} \\
\hline & Mobile device & 6.4286 & .97895 & & \\
\hline \multirow{2}{*}{$\begin{array}{l}\text { While I was navigating the website, I did not } \\
\text { have absolute control over what I could do on } \\
\text { the website }\end{array}$} & Computer & 4,8039 & 2,04958 & \multirow{2}{*}{1.941} & \multirow{2}{*}{.055} \\
\hline & Mobile device & 3.9592 & 2.29999 & & \\
\hline \multirow{2}{*}{ The website is not suitable for use } & Computer & 5.9020 & 1.28460 & \multirow{2}{*}{1.003} & \multirow{2}{*}{.319} \\
\hline & Mobile device & 5.5918 & 1.77856 & & \\
\hline \multicolumn{6}{|l|}{ POSSIBILITY OF RESPONSE } \\
\hline \multirow{2}{*}{ The website processes my inputs very quickly } & Computer & 5.1569 & 1.15538 & \multirow{2}{*}{-1.190} & \multirow{2}{*}{.237} \\
\hline & Mobile device & 5.4694 & 1.45920 & & \\
\hline \multirow{2}{*}{$\begin{array}{l}\text { Acquiring information from the website is } \\
\text { very fast }\end{array}$} & Computer & 5.6667 & 1.19443 & \multirow{2}{*}{-.449} & \multirow{2}{*}{.654} \\
\hline & Mobile device & 5.7755 & 1.22925 & & \\
\hline \multirow{2}{*}{$\begin{array}{l}\text { I was able to obtain the information I } \\
\text { wanted without delay }\end{array}$} & Computer & 5.5490 & 1.13690 & \multirow{2}{*}{-2.465} & \multirow{2}{*}{.015} \\
\hline & Mobile device & 6.0816 & 1.01728 & & \\
\hline \multirow{2}{*}{$\begin{array}{l}\text { When I click on a link I feel like I am } \\
\text { obtaining immediate information }\end{array}$} & Computer & 5.0980 & 1.66439 & \multirow{2}{*}{-1.997} & \multirow{2}{*}{.049} \\
\hline & Mobile device & 5.6735 & 1.16168 & & \\
\hline The website is very slow in responding to & Computer & 5.4706 & 1.75901 & & \\
\hline my requests & Mobile device & 5.3878 & 1.59186 & .241 & .806 \\
\hline The wehsite directly resnonded to my auestions & Computer & 3.8039 & 1.46996 & -1841 & 069 \\
\hline Ine weosite directiy responded to my questions & Mobile device & 4.3469 & 1.47974 & -1.841 & .009 \\
\hline ATTITUDE TOWARDS THE WEBSITE & & & & & \\
\hline & Computer & 5.8627 & 1.21687 & & \\
\hline 1 think the website is good & Mobile device & 6.0816 & 1.03756 & -.966 & .336 \\
\hline & Computer & 5.8039 & 1.13172 & & \\
\hline 1 think the website is suitable & Mobile device & 6.2041 & .95698 & -1.900 & .000 \\
\hline & Computer & 5.5882 & 1.38819 & & \\
\hline I think the website is appealing & Mobile device & 5.8776 & 1.20126 & -1.113 & .269 \\
\hline SATISFACTION & & & & & \\
\hline I am satisfied with my experience on & Computer & 5.4510 & 1.47396 & & \\
\hline the website & Mobile device & 5.6735 & 1.32897 & & .430 \\
\hline This experience of looking for a job online & Computer & 4.7843 & 1.57878 & & \\
\hline is exactly what I wanted & Mobile device & 5.5102 & 1.37117 & -2.451 & .010 \\
\hline This online experience was not similar to & Computer & 3.8039 & 1.26522 & & \\
\hline what I expected & Mobile device & 3.9796 & 1.46472 & & .522 \\
\hline OVERALL WEBSITE QUALITY & & & & & \\
\hline The overall quality of looking for a & Computer & 5.4706 & 1.20587 & -1431 & 156 \\
\hline job on the website is & Mobile device & 5.7755 & .89595 & -1.431 & .156 \\
\hline My feelinos for the wehsite are & Computer & 5.5882 & 1.08030 & & 762 \\
\hline viy reenings ior tne weosite are & Mobile device & 5.6531 & 1.05180 & & .102 \\
\hline LOYALTY INTENTION & & & & & \\
\hline I will encourage my friends and relatives & Computer & 4.8824 & 1.63275 & & 077 \\
\hline to look for a job on this website & Mobile device & 5.4286 & 1.41421 & -1.185 & $.01 /$ \\
\hline I will tell positive things about the website to & Computer & 5.1765 & 1.63347 & 1929 & 057 \\
\hline others & Mobile device & 5.7551 & 1.34676 & 1.929 & $.05 /$ \\
\hline I will use the website to look for a job in & Computer & 4.7451 & 1.75320 & 2437 & \\
\hline the upcoming period & Mobile device & 5.5714 & 1.63299 & -2.431 & .017 \\
\hline I would recommend this website to a & Computer & 5.1176 & 1.77366 & 563 & 012 \\
\hline person asking me for advice & Mobile device & 5.9184 & 1.30443 & -2.563 & .012 \\
\hline I consider this website my primary choice for & Computer & 4.0000 & 1.66132 & $-2,112$ & 037 \\
\hline acquiring information about jobs on the market & Mobile device & 4.7143 & 1.71998 & -2.112 & .031 \\
\hline
\end{tabular}

$\mathrm{M}$ - Arithmetic mean; SD - Standard deviation; $\mathrm{t}$ - the t-test, $\mathrm{p}$ - Statistical significance

The results presented in the table testify to the fact that respondents feel comfortable when using the website. For the purpose of research, the website was registered on Google Analytics, by the use of which we can obtain objective indicators of user behavior on the website. Table 3 shows the following parameters: total number of pages 
M. Jevremovic et al. Comparative analysis of the influence on consumers via mobile phones and computers

viewed, number of pages viewed per visit, page stay time, page exit rate.

Table 3: Overview of parameters monitored - Google Analytics

\begin{tabular}{|l|c|c|c|c|}
\hline & $\begin{array}{c}\text { Number of pages } \\
\text { viewed }\end{array}$ & $\begin{array}{c}\text { Number of pages } \\
\text { viewed per visit }\end{array}$ & Page stay time & Page exit rate \\
\hline Computer & 1104 & 11,16 & 15,48 & 11,7 \\
\hline Mobile device & 818 & 9,98 & 13,53 & 20,73 \\
\hline
\end{tabular}

Table 4: Overview of parameters monitored - Google Analytics

\begin{tabular}{|l|c|c|c|}
\hline & $\begin{array}{c}\text { Number of registered } \\
\text { respondents }\end{array}$ & $\begin{array}{c}\text { Number of registered } \\
\text { jobs/practices/training courses }\end{array}$ & $\begin{array}{c}\text { Average number of } \\
\text { applications per user }\end{array}$ \\
\hline Mobile device & 39 & 94 & 2.41 \\
\hline Computer & 38 & 87 & 2.29 \\
\hline
\end{tabular}

Another parameter showing an objective difference between the respondents who used the website on a computer and those who used it via mobile devices is the number of jobs/practices and training courses which the respondents from both groups applied for while using the website (Table 4).

\section{CONCLUSION}

On the basis of the conducted survey it has been determined that the respondents using computers for browsing have a weaker feeling that the company responds quickly to their inquiries and lower satisfaction when using the website, and that the connections created between the company and the users are weaker in terms of loyalty. When it comes to questions belonging to individual surveyed categories, although the Communications category did not show a statistically significant difference between the respondents who used mobile devices and those who used computers, the question whether the company offered a possibility of live conversation with a company representative showed a statistically significant difference, and a higher score was achieved by the respondents who used computers. As for the Possibility of Response category, where a statistically significant difference was recorded between the two groups of respondents, the questions showing a statistically significant difference pertained to the possibility of obtaining immediate information or information without delay. In those questions a higher score was achieved by the respondents who used mobile devices. The respondents who used mobile devices also achieved a higher score in the User Satisfaction category in the question whether the online experience was exactly what they expected. In the last category pertaining to the user loyalty intention, the respondents who used mobile phones achieved a higher score in the questions whether they would use the website to look for a job in the upcoming period, whether they would recommend the website to everyone asking for advice, and whether the observed website would be their primary choice for looking for a job/practice/training courses. On the other hand, objective indicators of the effects on users who have participated in the survey testify to the fact that higher involvement of respondents in terms of the number of pages viewed, number of pages viewed per visit, page stay time and page exit rate was achieved in respondents using computers in comparison with those using mobile devices. Based on the foregoing, it can be concluded that the use of mobile phones when browsing the Internet creates a feeling of a greater influence by the company in users, while their actions show the opposite. In this case, the feeling created in users does not match the actions taken by users. The ultimate goal of the company's website in marketers is the final action that the user takes on the website, regardless of whether it is an application, purchase, takeover, etc. In this survey, the website was used for the purpose of investigating the degree of its influence on website users, while the expected ultimate action of the users was an application for a job/practice/training course.

The differences between the respondents who used mobile devices and those who used computers during the survey are small, i.e. a very small percentage of mobile device users achieved better results, and it can therefore be concluded that the use of various devices when browsing the content on the Internet does not influence the consumers' decisions on taking the final action, i.e. purchase, application, order, etc. 


\section{REFERENCES}

Albert, T. C., Goes, P. B., \& Gupta., A. (2004). GIST: A model for design and management of content and interactivity of customer-centric web sites: MIS Quarterly.

Chaffey, D. (2016). Marketing Trends for 2016 - Will we be in a post-digital era? Retrieved 07.03, 2016, from http://www.smartinsights.com/managingdigital-marketing/marketing-innovation/marketingtrends-2016/

Chung, H., \& Zhao, X. (2004). Effects of Perceived Interactivity on Web Site Preference and Memory: Role of Personal Motivation. Journal of ComputerMediated Communication, 10(1).

Krum, C. (2010). Mobile Marketing Finding Your Customers No Matter Where They Are. Indiana, . USA: Pearson Education, Inc.

Downes, E. J., \& McMillan, S. J. (2000). Defining interactivity: a qualitative identification of key dimensions. New Media and Society, 2(2), 157-179.

Hoffman, D. L., \& Novak, T. P. (1996). Marketing in hypermedia computer-mediated environments: Conceptual Foundations. Journal of Marketing, 60(3), 50-68.

Jiang, Z., Chan, J., Tan, B. C. Y., \& Chua, W. S. (2010). Effects of Interactivity on Website Involvement and Purchase Intention. Journal of the Association for Information Systems, 11(1), 34-59.

Johnson, G. J., Bruner, G. C., \& Kumar, A. (2006). Interactivity and its facets revisited. Journal of Advertising, 35(4), 35-52.

Liu, Y. P. (2003). Developing a scale to measure the interactivity of web sites. Journal of Advertising Research, 43, 207-216.

Liu, Y. P., \& J., S. L. (2002). What is interactivity and is it always such a good thing? Implications of definition, person and situation for the influence of interactivity on advertising effectiveness. Journal of Advertising, 31(4), 53-64.

Matti, L., \& Heikki, K. (2008). Mobile marketing: From marketing strategy to mobile marketing campaign implementation. International Journal of Mobile Marketing, 3(1), 50-61.

McMillan, S. J. (2002). A four-part model of cyberinteractivity. SAGE Publications, 4(2), 271-291.

McMillan, S. J., \& Hwang, J.-S. (2002a). Measures of Perceived Interactivity: An Exploration of the Role of Direction of Communication, User Control, and Time in Shaping Perceptions of Interactivity. Journal of advertising, 31(3), 29-42.

Miller, M. (2010). The Ultimate Web Marketing Guide: Pearson Education, Inc.
Michael, A., \& Salter, B. (2006). Mobile marketing: Routledge.

Newhagen, J. E., Cordes, J. W., \& Levy, M. R. (1995). Audience Scope and the Perception of Interactivity in Viewer Mail on the Internet. Journal of Communication, 45(3), 164-175.

Pasqua R., \& N., E. (2013). Mobile Marketing: An Hour a Day. Indianapolis, Indiana: John Wiley \& Sons, Inc.

Qin, G., Rau, P.-L. P., \& Salvendy, G. (2010). Measuring perceived interactivity of mobile advertising. Behaviour and Information Technology, 29(1), 35-44.

Scharl, A., Dickinger, A., \& Murphy, J. (2005). Diffusion and success factors of mobile marketing. Electronic Commerce Research and Applications, 4(2), 159-173

Shankar, V., Smith, A. K., \& Rangaswamy, A. (2003). Customer satisfaction and loyalty in online and offline environments. International Journal of Research in Marketing, 20(2), 153-175.

Smutkupt, P., Krairit, D., \& Esichaikul, V. (2010). Mobile marketing: Implications for marketing strategies. International Journal of Mobile Marketing, 5(2), 126-139.

Song, J. H., \& M., Z. G. (2008). Determinants of Perceived Web Site Interactivity. Journal of marketing, 72, 99-133.

VanBoskirk, S. (2011). US Interactive Marketing Forecast 2011 To 2016. Retrieved 20.12.2015, from Forrester Research, Inc http://www.bcama.com/documents/Forrester_interac tive marketing forecast 2011 to 2016.pdf

Vasić, Ž., M., J., \& N., J. (2011). Requirements for successful company presentation on the internet. Paper presented at the MIT, Vrnjačka Banja.

Wu, G. (1999). Perceived Interactivity and Attitude toward Website. Paper presented at the Annual Conference of American Academy of Advertising Albuquerque, New Mexcio.

$\mathrm{Wu}, \mathrm{G}$. (2006). Conceptualizing and Measuring the Perceived Interactivity of Websites. Journal of Current Issues \& Research in Advertising (CTC Press), 28(1), 87-104.

Yuping, L. (2003). Developing a Scale to Measure the Interactivity of Web Sites. Journal of advertising research, 43(2), 207-216.

Yuping, L., \& Shrum, L. J. (2002). What Is Interactivity and Is It Always Such a Good Thing? Implications of Definition, Person, and Situation for the Influence of Interactivity on Advertising Effectiveness. Journal of advertising, 31(4), 53-64. 


\section{KOMPARATIVNA ANALIZA UTICAJA NA POTROŠAČE PUTEM MOBILNOG UREĐAJA I RAČUNARA}

Poslovanje danas karakteriše brz razvoj tehnologije, tako da marketari traže najefikasniji način da skrenu pažnju potrošača o svom poslovanju i na taj naćin zauzmu mesto u njihovoj svesti. Posedovanje i korišćenje mobilnog telefona je postalo sastavni deo svakog potrošača. Ovaj rad istražuje da li postoje i kolike su razlike u stepnu uticaja na potrošače koji reklamni sadržaj posmatraju putem mobilnih telefona u odnosu na uticaj na potrošače koji isti sadržaj posmatraju putem računara, kao i da li se razlikuje mišljenje ispitanika o interaktivnosti (percipirana interaktivnost) sadržaja koji posmatraju u odnosu na stvarnu interaktivnost koja postoji.

Ključne reči: Perceptivna interaktivnost, Korisnici, Mobilni marketing. 